\title{
Measurements of $\mathrm{CO}_{2}$, its stable isotopes, $\mathrm{O}_{2} / \mathrm{N}_{2}$, and ${ }^{222} \mathrm{Rn}$ at Bern, Switzerland
}

\author{
P. Sturm, M. Leuenberger, F. L. Valentino, B. Lehmann, and B. Ihly \\ Climate and Environmental Physics, Physics Institute, University of Bern, Bern, Switzerland \\ Received: 20 May 2005 - Published in Atmos. Chem. Phys. Discuss.: 9 September 2005 \\ Revised: 29 November 2005 - Accepted: 3 April 2006 - Published: 8 June 2006
}

\begin{abstract}
A one-year time series of atmospheric $\mathrm{CO}_{2}$ measurements from Bern, Switzerland, is presented. $\mathrm{O}_{2} / \mathrm{N}_{2}$ and $\mathrm{Ar} / \mathrm{N}_{2}$ ratios as well as stable carbon and oxygen isotopes of $\mathrm{CO}_{2}$ and $\delta^{29} \mathrm{~N}_{2}, \delta^{34} \mathrm{O}_{2}$ and $\delta^{36} \mathrm{Ar}$ were measured periodically during a one year period. Additionally, the ${ }^{222} \mathrm{Rn}$ activity was measured during three months in the winter 2004. Using the correlation from short-term fluctuations of $\mathrm{CO}_{2}$ and ${ }^{222} \mathrm{Rn}$ we estimated a mean $\mathrm{CO}_{2}$ flux density between February 2004 and April 2004 in the region of Bern of $95 \pm 39 \mathrm{tC} \mathrm{km}^{-2}$ month $^{-1}$. The continuous observations of carbon dioxide and associated tracers shed light on diurnal and seasonal patterns of the carbon cycle in an urban atmosphere. There is considerable variance in nighttime $\delta^{13} \mathrm{C}$ and $\delta^{18} \mathrm{O}$ of source $\mathrm{CO}_{2}$ throughout the year, however, with generally lower values in winter compared to summertime. The $\mathrm{O}_{2}: \mathrm{CO}_{2}$ oxidation ratio during the nighttime build-up of $\mathrm{CO}_{2}$ varies between -0.96 and $-1.69 \mathrm{~mol} \mathrm{O}_{2} / \mathrm{mol} \mathrm{CO}_{2}$. Furthermore, $\mathrm{Ar} / \mathrm{N}_{2}$ measurements showed that artifacts like thermal fractionation at the air intake are relevant for high precision measurements of atmospheric $\mathrm{O}_{2}$.
\end{abstract}

\section{Introduction}

We present continuous records of atmospheric $\mathrm{CO}_{2}$ and associated tracers measured in the city of Bern, Switzerland. At this urban site, anthropogenic $\mathrm{CO}_{2}$ emissions (e.g., car exhausts, heating) mix with the background and biogenic $\mathrm{CO}_{2}$ components, which are influenced by circulation, photosynthesis and respiration. Local sources and sinks in the catchment area of Bern and changing meteorological conditions are expected to lead to large short-term variations of the observed tracers. In order to be able to interpret and apportion

Correspondence to: M. Leuenberger

(leuenberger@climate.unibe.ch) these observations high-resolution measurements of multiple tracers are needed.

Stable carbon and oxygen isotopes in atmospheric $\mathrm{CO}_{2}$ can be used to measure the size of the $\mathrm{CO}_{2}$ fluxes and to discriminate between the various processes in the carbon cycle. Photosynthetic uptake of $\mathrm{CO}_{2}$, plant and soil respiration, and fossil fuel burning lead to carbon and oxygen isotope signals of atmospheric $\mathrm{CO}_{2}$, which can be used as a tracer at various temporal and spatial scales (Friedli et al., 1987; Keeling et al., 1989; Ciais et al., 1997a). Hesterberg (1990) has measured $\delta^{13} \mathrm{C}$ and $\delta^{18} \mathrm{O}$ of $\mathrm{CO}_{2}$ in Bern during a one-year period in 1988/89. His measurements of flask samples collected twice a week showed seasonal differences in the $\delta^{13} \mathrm{C}$ and $\delta^{18} \mathrm{O}$ signals (Fig. 1). Another approach involves measuring changes of the atmospheric oxygen $\left(\mathrm{O}_{2}\right)$ concentration. $\mathrm{O}_{2}$ and $\mathrm{CO}_{2}$ are inversely coupled by photosynthesis, respiration and combustion. However, the different processes have different $\mathrm{O}_{2}: \mathrm{CO}_{2}$ exchange ratios and thus can be distinguished from each other. The high precision of $\mathrm{O}_{2}$ measurements that is necessary to constrain such carbon fluxes, has given new insights into gas handling procedures and fractionation effects (Bender et al., 1994; Keeling et al., 1998; Langenfelds, 2002). Though continuous on-line measurements circumvent any storage related effects as observed in some flask sampling programs (Sturm et al., 2004), they are still susceptible to diffusive fractionation processes. Fractionation of $\mathrm{O}_{2} / \mathrm{N}_{2}$ at the intake as well as at tees have first been observed by Manning (2001) and have been attributed to molecular thermal diffusion. Fractionation at tees is dependent on the geometry of the tee and the flow ratio at the two outlet branches of the tee. The larger the flow ratio is, the more the tee is subject to fractionation. Yet, the exact cause and the points at which fractionation can occur in the flow path of air are still not well established. Molecular thermal diffusion results from temperature gradients. Heavier molecules generally accumulate in the colder region hence leading to concentration changes

Published by Copernicus GmbH on behalf of the European Geosciences Union. 


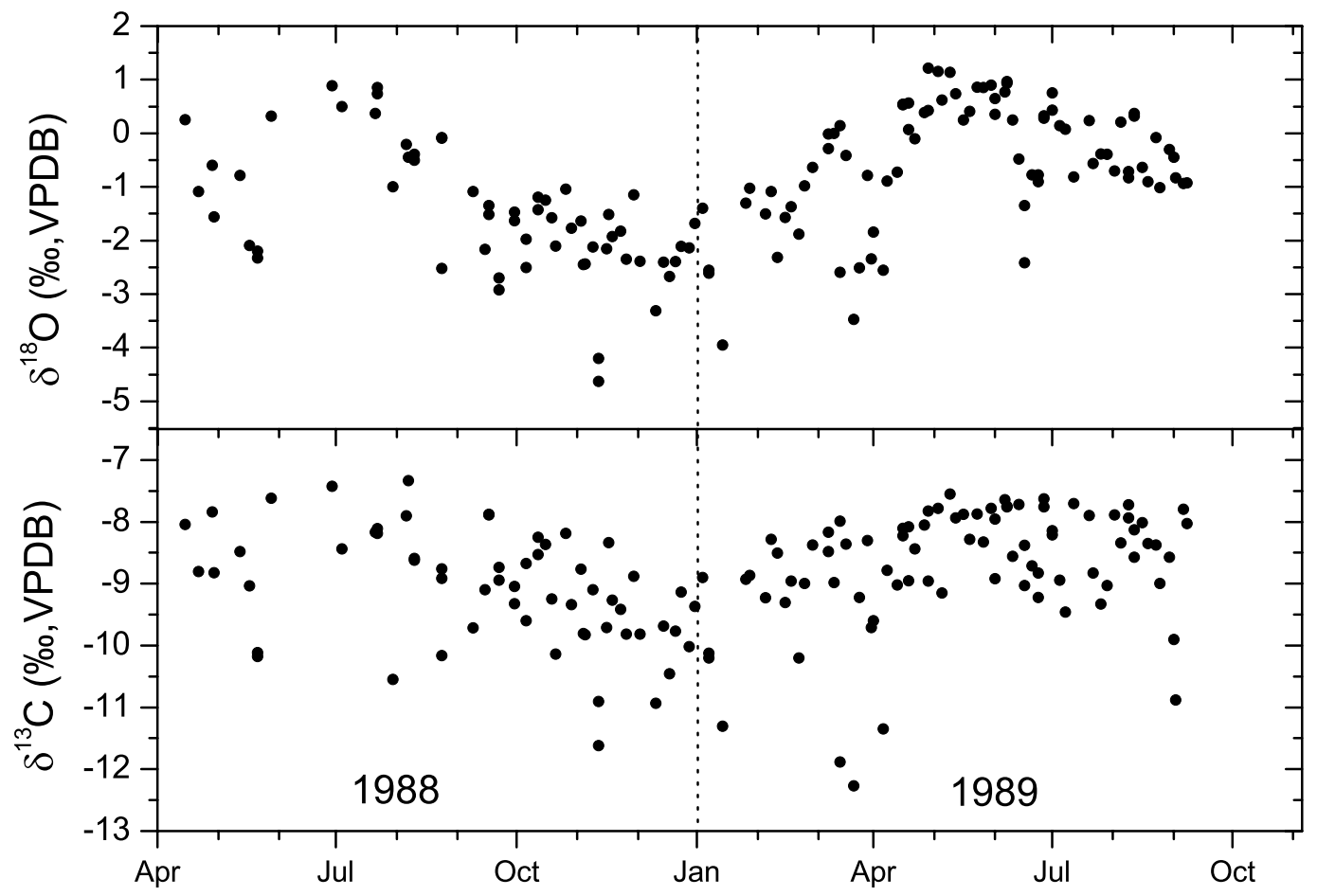

Fig. 1. $\delta^{13} \mathrm{C}$ and $\delta^{18} \mathrm{O}$ of $\mathrm{CO}_{2}$ in Bern during a one-year period in 1988/89 (Hesterberg, 1990).

(Severinghaus et al., 1996; Chapman and Cowling, 1970).

Radon-222 is a radioactive noble gas with a half-life $T_{1 / 2}$ of 3.82 days. It is produced in all soils as part of the natural uranium-radium $\alpha$-decay series and it emanates into the soil air and diffuses to the atmosphere where it is diluted by atmospheric transport and radioactive decay. The ${ }^{222} \mathrm{Rn}$ flux from ocean surfaces is about two orders of magnitude smaller than from continents (Wilkening and Clements, 1975). Because ${ }^{222} \mathrm{Rn}$ emissions from soils turned out to be rather homogeneous in a restricted region and relatively constant in time, ${ }^{222} \mathrm{Rn}$ is a useful tracer to parameterize transport and dilution in the atmospheric boundary layer (World Meteorological Organisation, 2004).

This paper first summarizes sampling and analysis techniques and reports on tests we have performed to assess fractionation effects at the air intake. Results for $\mathrm{CO}_{2}$, its stable isotopes, $\mathrm{O}_{2} / \mathrm{N}_{2}$ and ${ }^{222} \mathrm{Rn}$ over roughly a one-year period are described and possible mechanisms for these observations are discussed.

\section{Sampling and analysis techniques}

\subsection{Sampling site}

The city of Bern (about 127000 inhabitants) is situated on the Swiss Plateau. The measurements were made at the Physics Institute, University of Bern (PIUB), which is located on the eastern edge and about $20 \mathrm{~m}$ above the city center. The building is surrounded by residential and urban areas. The air is collected from the roof of the building $\left(46^{\circ} 57^{\prime} 04^{\prime \prime} \mathrm{N}\right.$, $7^{\circ} 26^{\prime} 20^{\prime \prime} \mathrm{E}, 575 \mathrm{~m}$ a.s.1.) about $15 \mathrm{~m}$ above local ground. Meteorological measurements were made by the Institute for Applied Physics, University of Bern. The weather station is located at the same height about $10 \mathrm{~m}$ away from the air intake. The sample air is sucked through a $\sim 40 \mathrm{~m}$ long $6 \mathrm{~mm}$ outer diameter Dekabon tube into our laboratory. We use a diaphragm pump (KNF Neuberger, Switzerland, N86KNDC with EPDM diaphragm). The flow rate is between 100 and $300 \mathrm{~mL} \mathrm{~min}^{-1}$ depending on which instruments are connected to the air stream. The air is dried cryogenically at $-70^{\circ} \mathrm{C}$. The total volume of the cold trap (about $250 \mathrm{~mL}$ ) restricts the time resolution of the measurements to about $2 \mathrm{~min}$.

\section{$2.2 \mathrm{CO}_{2}$ mixing ratio}

The $\mathrm{CO}_{2}$ mixing ratio was measured by non-dispersive infrared adsorption (NDIR) technique. In the beginning the $\mathrm{CO}_{2}$ measurements were performed by a S710 UNOR $\mathrm{CO}_{2}$ analyzer (SICK MAIHACK GmbH, Germany). From March 2004 a LI-7000 $\mathrm{CO}_{2} / \mathrm{H}_{2} \mathrm{O}$ analyzer (LI-COR, USA), was used. The flow rate of the sample gas is about $100 \mathrm{~mL} \mathrm{~min}^{-1}$ and every minute the mean $\mathrm{CO}_{2}$ mixing ratio is recorded. The $\mathrm{CO}_{2}$ data are reported on the WMO $\mathrm{CO}_{2}$ mole fraction scale. Primary standards from NOAA/CCGG, Boulder, $\mathrm{CO}$, USA, are used to calibrate the working and secondary 


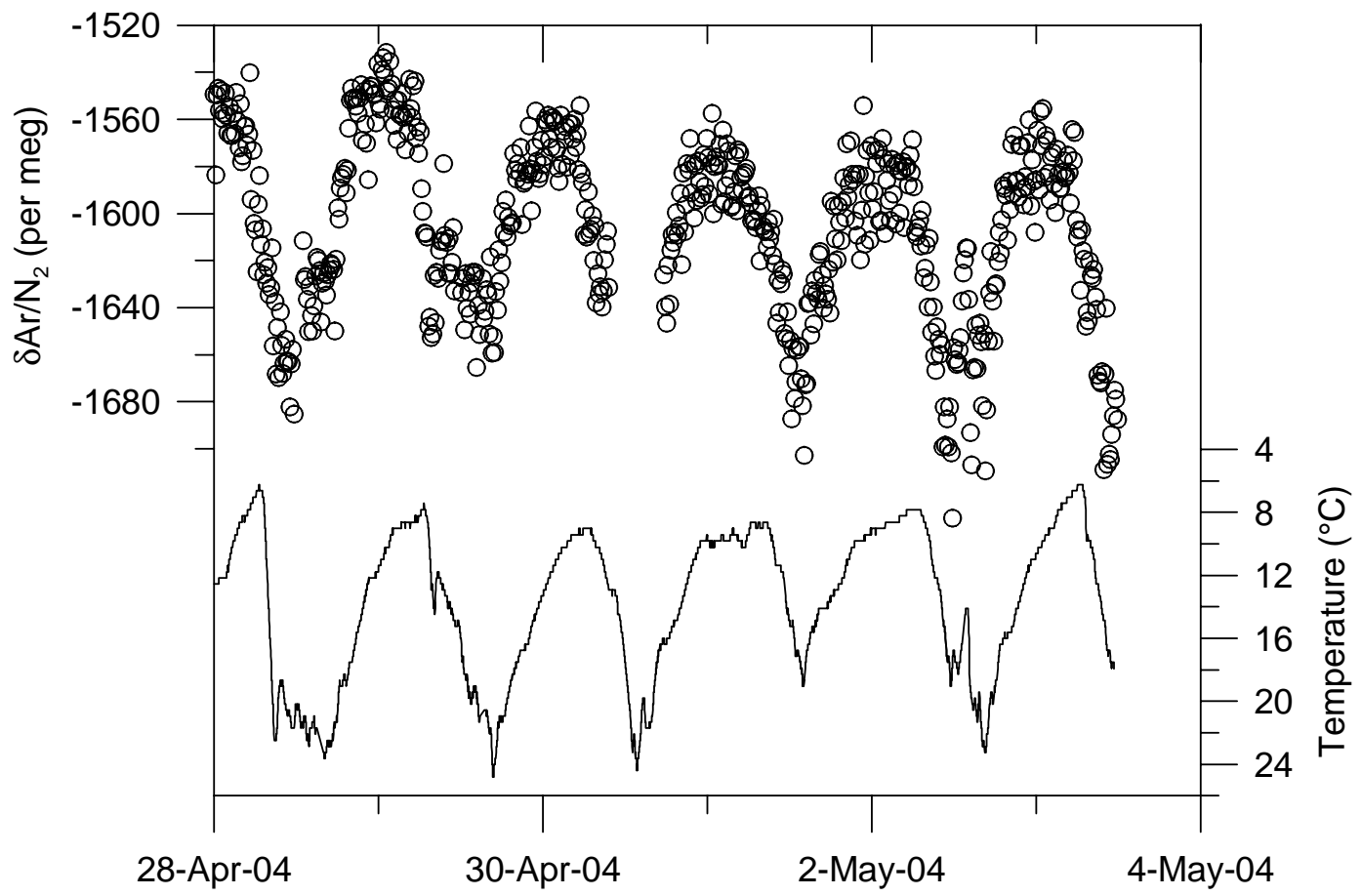

Fig. 2. Diurnal variations of $\delta \mathrm{Ar} / \mathrm{N}_{2}$ (top) and outdoor temperature (bottom). Note the inverted axis of the temperature.

standards. However, the $\mathrm{CO}_{2}$ mixing ratio of these primary standards lies in the range of 192 to $363 \mathrm{ppm}$. The calibration of our $\mathrm{CO}_{2}$ scale above $363 \mathrm{ppm}$ is therefore based on extrapolation. Still, the accuracy of the $\mathrm{CO}_{2}$ data is estimated to be better than $\pm 0.5 \mathrm{ppm}$ for mixing ratios below $400 \mathrm{ppm}$ and better than $\pm 1 \mathrm{ppm}$ for 400 to $450 \mathrm{ppm}$.

\section{$2.3 \delta^{13} \mathrm{C}$ and $\delta^{18} \mathrm{O}$ of $\mathrm{CO}_{2}$}

The carbon and oxygen isotopes of $\mathrm{CO}_{2}$ were determined in a semi-continuous way by an on-line $\mathrm{CO}_{2}$ trapping system connected to a mass spectrometer (Leuenberger et al., 2003). Every $12 \mathrm{~min} \mathrm{CO}_{2}$ from an air parcel of about $0.5 \mathrm{~mL}$ STP was cryogenically trapped in a glass capillary. The small $\mathrm{CO}_{2}$ amount is then released into a low helium stream $(1 \mathrm{~mL} \mathrm{~min}-1)$. This gas stream is additionally split into three similar fluxes entering capillaries of different lengths. A multi-port valve handles the flow path such that the three gas portions are injected one after another via an open split device to an isotope ratio mass spectrometer (DELTA ${ }^{\text {plus }} \mathrm{XL}$, Thermo Electron, Bremen, Germany), where the $m / z$ ratios $45 / 44$ and $46 / 44$ of the $\mathrm{CO}_{2}$ are measured. The precision of this method estimated by the pooled standard deviations of the triplicate measurements is about $\pm 0.08 \%$ o for $\delta^{13} \mathrm{C}$ and $\pm 0.12 \%$ for $\delta^{18} \mathrm{O}$. Constant $\mathrm{N}_{2} \mathrm{O}$ corrections of $-0.23 \%$ and $-0.35 \%$ are applied to the $\delta^{13} \mathrm{C}$ and $\delta^{18} \mathrm{O}$ data, respectively. Variations in the $\mathrm{N}_{2} \mathrm{O} / \mathrm{CO}_{2}$ concentration ratio of the sample air would lead to varying $\mathrm{N}_{2} \mathrm{O}$ corrections, but such effects are expected to be small compared to the measurement precision. Carbon and oxygen isotopic compositions are expressed on the Vienna Pee Dee Belemnite (VPDB-CO ${ }_{2}$ ) standard scale (Coplen, 1994; IAEA, 1995).

$\delta^{18} \mathrm{O}$ measurements from flask sampling often face additional experimental problems, due to the risk of isotopic exchange of $\mathrm{CO}_{2}$ with water, that may occur anywhere in the sample treatment from the moment of sampling until the admission of the sample in the mass spectrometer (Gemery et al., 1996). For example, isotope exchange during flask storage of $\mathrm{CO}_{2}$ with water, that permeates through the flask seals (Sturm et al., 2004), interferes with any real atmospheric signal. Our flask measurements of $\delta^{18} \mathrm{O}$ from Jungfraujoch, Puy de Dôme and Griffin (Sturm et al., $2005 \mathrm{~b}, \mathrm{a})$ are therefore believed not to represent the true isotopic composition of atmospheric $\mathrm{CO}_{2}$. Therefore the advantage of the continuous analysis method used here, apart from the high time resolution, is that such storage related effects can largely be circumvent.

\subsection{Elemental and isotopic ratios of air}

The elemental ratios $\mathrm{O}_{2} / \mathrm{N}_{2}$ and $\delta \mathrm{Ar} / \mathrm{N}_{2}$ as well as the isotopic ratios $\delta^{29} \mathrm{~N}_{2}, \delta^{34} \mathrm{O}_{2}$ and $\delta^{36} \mathrm{Ar}$ are analyzed by an iso-

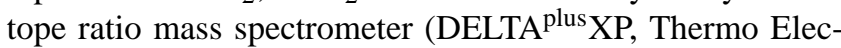
tron, Bremen, Germany) and expressed in the $\delta$-notation as per meg deviation from our local PIUB reference gas. A glass capillary at a tee takes about $0.2 \mathrm{~mL} \mathrm{~min}^{-1}$ of the flow to the gas inlet system (Leuenberger et al., 2000; Sturm, 2001) of the mass spectrometer. One measurement 


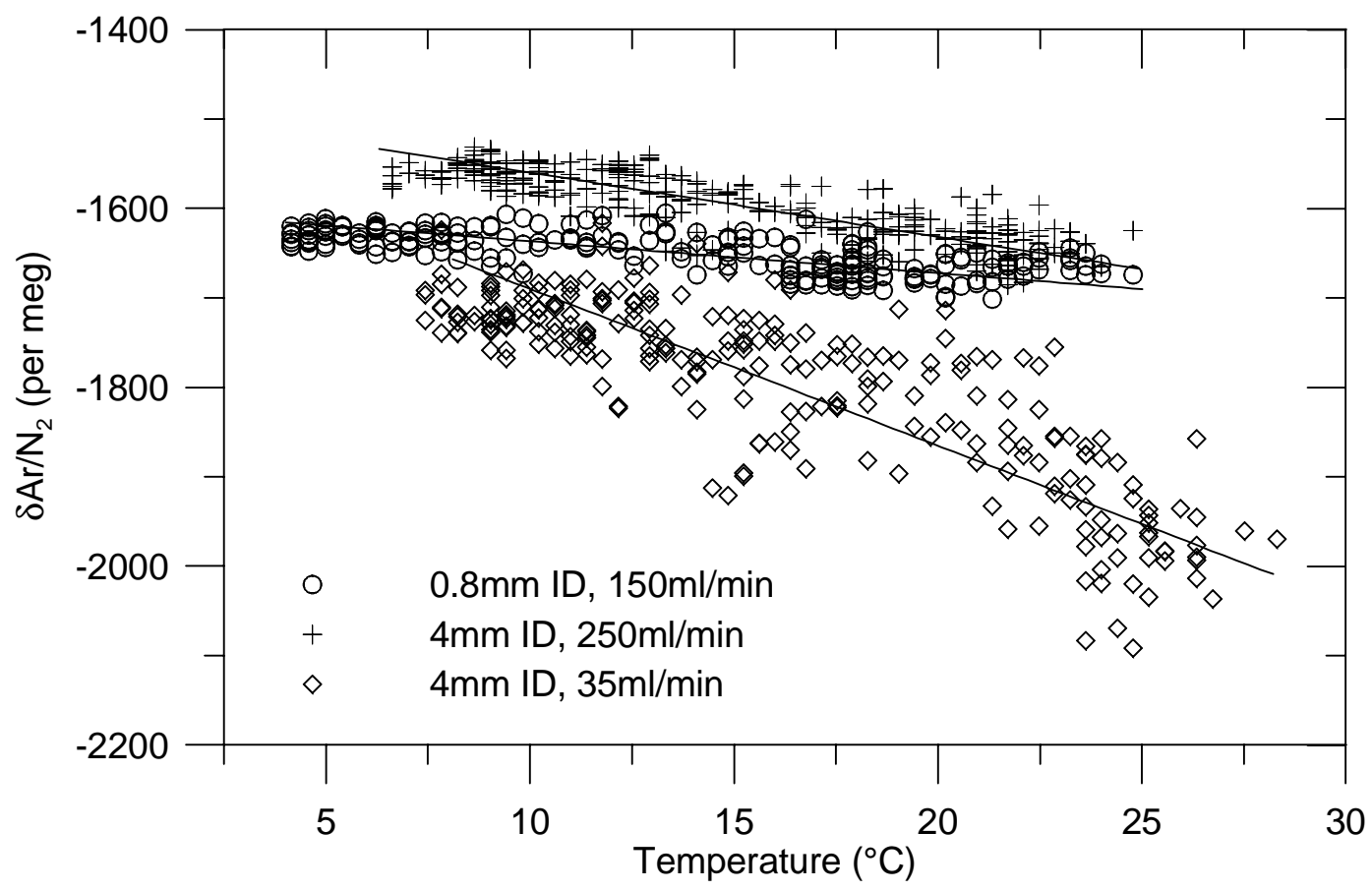

Fig. 3. Correlation of $\delta \mathrm{Ar} / \mathrm{N}_{2}$ and outdoor temperature for different types of air intake.

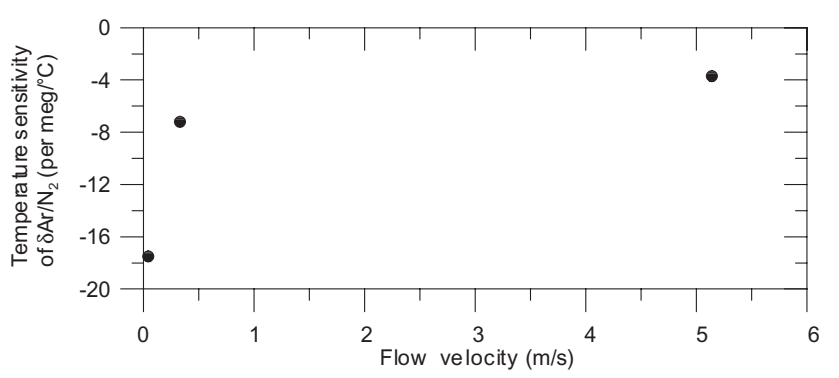

Fig. 4. Temperature sensitivity of $\delta \mathrm{Ar} / \mathrm{N}_{2}$ depending on the gas velocity at the air intake for the three experiments of Fig. 3.

comprises eight standard/sample cycles and takes about $12 \mathrm{~min}$. Hence one data point represents a mean concentration of the last $12 \mathrm{~min}$.

\section{$2.5 \quad{ }^{222} \mathrm{Rn}$ activity}

The specific ${ }^{222} \mathrm{Rn}$ activity is measured by an alphadecay detector (Alphaguard 2000 Pro, Genitron Instruments, Frankfurt, Germany). The instrument was placed on the roof of the PIUB building, about $10 \mathrm{~m}$ next to the air intake. Using digital signal processing for pulse shape analysis the detection limit of the detector in a 10-min measuring interval is about $3 \mathrm{~Bq} \mathrm{~m}^{-3}$ (Lehmann et al., 2004). The radon activity is reported as hourly mean values.

\section{Results and discussion}

3.1 Temperature dependent fractionation at the air intake

The $\mathrm{Ar} / \mathrm{N}_{2}$ ratio can be measured simultaneously with $\mathrm{O}_{2} / \mathrm{N}_{2}$ and is a useful tracer to reveal fractionation effects. Only the temperature dependence of the gas solubility in seawater leads to seasonal variations in air-sea fluxes and small changes in atmospheric $\mathrm{Ar} / \mathrm{N}_{2}$ ratio (Keeling et al., 2004). On diurnal timescales, however, the atmospheric $\mathrm{Ar} / \mathrm{N}_{2}$ ratio is expected to be constant, because no biogeochemical processes influence these inert gases. However, our $\mathrm{Ar} / \mathrm{N}_{2}$ measurements revealed large variability. Diurnal variations of $\delta \mathrm{Ar} / \mathrm{N}_{2}$ and outdoor temperature are shown as an example in Fig. 2. The outdoor temperature was measured by a HOBO H8 data logger (Onset Computer Corporation, MA, USA) placed at the bottom of the intake pole. The air intake is a Dekabon tube with $4 \mathrm{~mm}$ inner diameter (ID) and the flow rate was about $250 \mathrm{~mL} \mathrm{~min}^{-1}$. The higher the air temperature is, the lower the $\delta \mathrm{Ar} / \mathrm{N}_{2}$ gets.

To assess the causes of the observed $\delta \mathrm{Ar} / \mathrm{N}_{2}$ variations and to better quantify this effect, we conducted tests with different intake tubes and sampling flows. In addition to the Dekabon tube with flow rates of $250 \mathrm{~mL} \mathrm{~min}^{-1}$ and $35 \mathrm{~mL} \mathrm{~min}^{-1}$, also a stainless steel tube with $0.8 \mathrm{~mm}$ ID and a flow rate of $155 \mathrm{~mL} \mathrm{~min}^{-1}$ was used. The correlation of $\delta \mathrm{Ar} / \mathrm{N}_{2}$ and outdoor temperature for different types of air intakes is shown in Fig. 3. Remarkably, the temperature records lag the $\delta \mathrm{Ar} / \mathrm{N}_{2}$ variations by 90 to $150 \mathrm{~min}$. This 

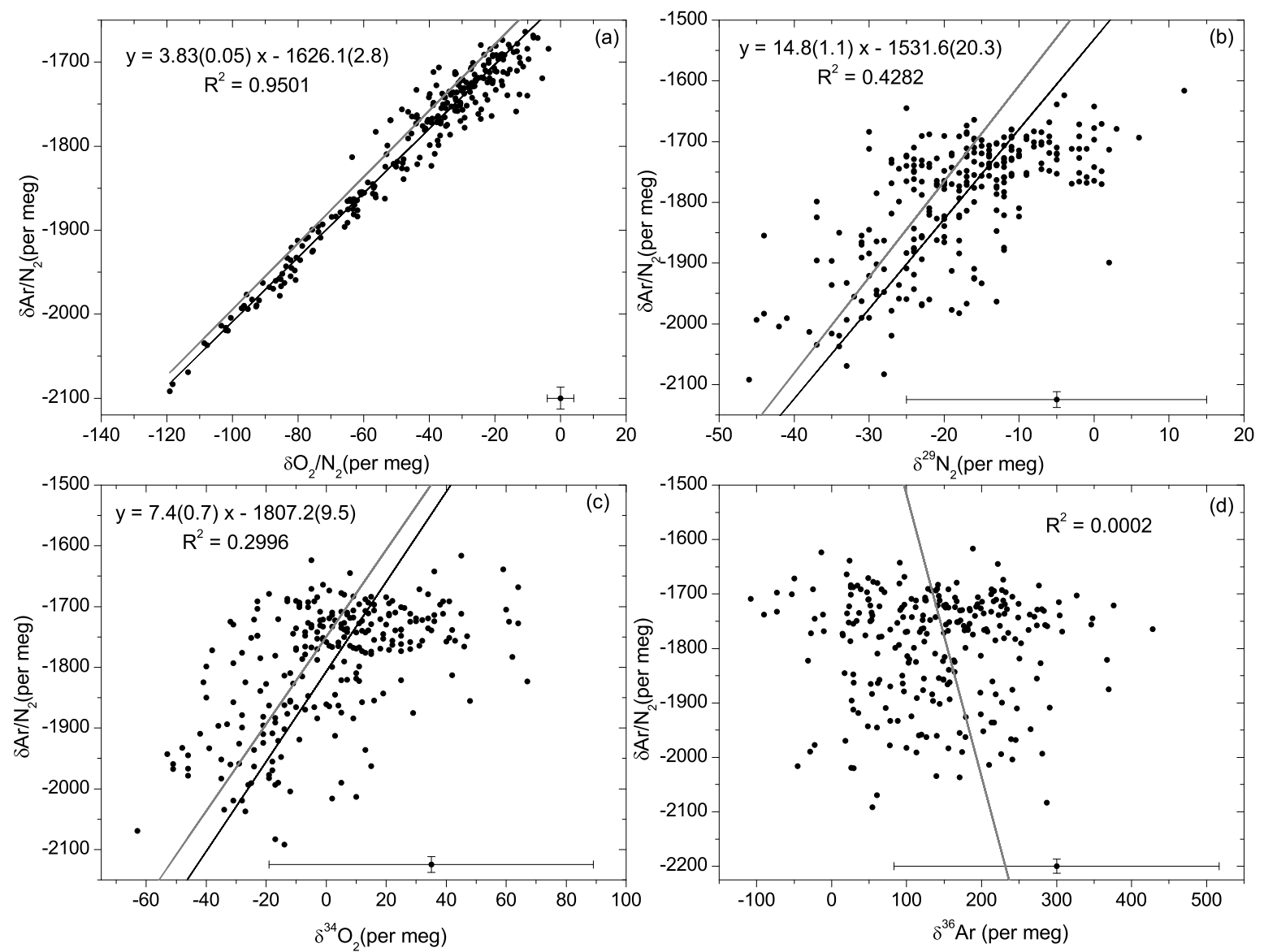

Fig. 5. Correlation plots of $\delta \mathrm{Ar} / \mathrm{N}_{2}$ versus $\mathrm{O}_{2} / \mathrm{N}_{2}, \delta^{29} \mathrm{~N}_{2}, \delta^{34} \mathrm{O}_{2}$ and $\delta^{36} \mathrm{Ar}$ for the " $4 \mathrm{~mm} \mathrm{ID/35} \mathrm{mL} \mathrm{min}{ }^{-1}$ " experiment (see text). Grey lines represent the expected correlation slopes obtained from the ratios of the thermal diffusion factors for the respective isotopes and elements. Black lines are the measured regression slopes using the associated errors as shown in the bottom part of each graph.

is probably due to a slow response of the temperature logger used for these tests and the fact that the temperature sensor was not exposed to sunlight in contrast to the air intake. This time shift was applied in the calculations of Fig. 3 to obtain the best correlation. The temperature sensitivities obtained by geometric mean regression are $-17.5 \pm 0.6 \mathrm{per} \mathrm{meg} /{ }^{\circ} \mathrm{C}$ $\left(R^{2}=0.70\right),-7.2 \pm 0.2 \mathrm{per} \mathrm{meg} /{ }^{\circ} \mathrm{C}\left(R^{2}=0.71\right)$ and $-3.6 \pm$ 0.2 per meg $/{ }^{\circ} \mathrm{C}\left(R^{2}=0.51\right)$ for the " $4 \mathrm{~mm} \mathrm{ID} / 35 \mathrm{~mL} \mathrm{~min}{ }^{-1}$ ", " $4 \mathrm{~mm} \mathrm{ID/250} \mathrm{mL} \mathrm{min}^{-1}$ " and " $0.8 \mathrm{~mm} \mathrm{ID} / 155 \mathrm{~mL} \min ^{-1}$ ", experiments, respectively. As shown in Fig. 4, the temperature sensitivities of $\delta \mathrm{Ar} / \mathrm{N}_{2}$ mainly depend on the gas velocity at the air intake.

Variations of the laboratory temperature can also potentially influence the $\delta \mathrm{Ar} / \mathrm{N}_{2}$ measurements. Especially in summer there is a diurnal cycle of the laboratory temperature with amplitudes of 2 to $3^{\circ} \mathrm{C}$. However, the most striking feature of the diurnal temperature variations in the laboratory is a rapid drop of about $3^{\circ} \mathrm{C}$ at midnight caused by the air-conditioning. Because in these experiments no change in $\delta \mathrm{Ar} / \mathrm{N}_{2}$ can be observed at midnight, the variations in $\delta \mathrm{Ar} / \mathrm{N}_{2}$ are indeed mainly caused by fractionation at the air intake. This supposition was further confirmed by actively heating the intake tube, which resulted in large $\delta \mathrm{Ar} / \mathrm{N}_{2}$ deviations. An explanation is that during the day especially when the sun heats the black coating of the Dekabon tube, there builds up a small temperature gradient between the intake tube and the surrounding air. This leads to thermal diffusion with preferential accumulation of the lighter molecules in regions with higher temperatures. A thermal diffusion factor for Ar in $\mathrm{N}_{2}$ of $\alpha=0.071$ (Grew and Ibbs, 1952) would lead to a steady state fractionation of $240 \mathrm{per} \mathrm{meg} /{ }^{\circ} \mathrm{C}$. However, a steady state is not achieved at the intake because of the continuous flow of gas. Even though, the lower the flow velocity the more the air can approach a steady state. The slope of the correlation plot of $\delta \mathrm{Ar} / \mathrm{N}_{2}$ versus $\mathrm{O}_{2} / \mathrm{N}_{2}$ for the " $4 \mathrm{~mm} \mathrm{ID/35} \mathrm{mL} \mathrm{min}^{-1}$ " and the intake heating experiments gives $3.8 \pm 0.1$ (Fig. 5a). This is in good accordance with what is expected from thermal fractionation. With the thermal diffusion factors of Grew and Ibbs (1952) one would expect a slope of 3.9. Keeling et al. (2004) obtained a value of $3.77 \pm 0.04$. 


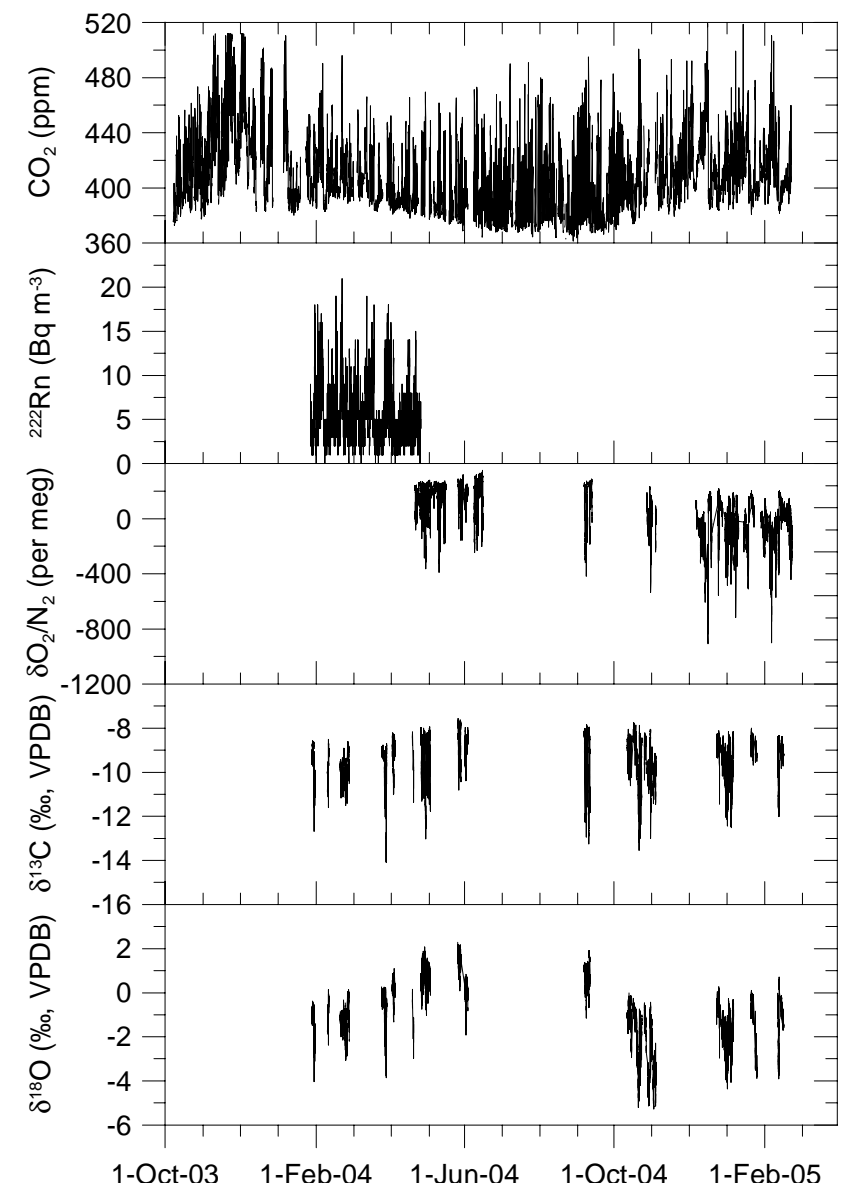

Fig. 6. Atmospheric records of $\mathrm{CO}_{2},{ }^{222} \mathrm{Rn}, \mathrm{O}_{2} / \mathrm{N}_{2}, \delta^{13} \mathrm{C}$ and $\delta^{18} \mathrm{O}$ of $\mathrm{CO}_{2}$ at Bern between October 2003 and February 2005.

The isotopic ratios $\delta^{29} \mathrm{~N}_{2}, \delta^{34} \mathrm{O}_{2}$ and $\delta^{36} \mathrm{Ar}$ show also small variations that are correlated with the temperature, providing compelling evidence of diffusive fractionation. However the signal-to-noise ratio relative to measurement precision is much higher for $\mathrm{Ar} / \mathrm{N}_{2}$ than for $\delta^{29} \mathrm{~N}_{2}, \delta^{34} \mathrm{O}_{2}$ or $\delta^{36} \mathrm{Ar}$, because $\mathrm{Ar} / \mathrm{N}_{2}$ is more sensitive to mass-dependent fractionation processes owing to the comparatively large mass difference between $\mathrm{Ar}$ and $\mathrm{N}_{2}$. Figure $5 \mathrm{~b}, \mathrm{c}$ and $\mathrm{d}$ show the correlation plots of $\delta \mathrm{Ar} / \mathrm{N}_{2}$ versus $\delta^{29} \mathrm{~N}_{2}, \delta^{34} \mathrm{O}_{2}$

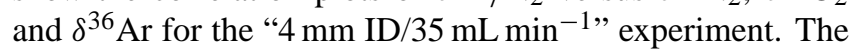
mass spectrometric uncertainty is indicated by error bars in the lower right corner of each plot. Regression lines (black lines) were calculated in Figs. 5a, b and c using a measurement error model which accounts for the relative magnitude of the errors in both variables (Fuller, 1987). There is no correlation between $\delta \mathrm{Ar} / \mathrm{N}_{2}$ and $\delta^{36} \mathrm{Ar}$ (Fig. 5d). The thermal diffusion factors $\alpha$ of ${ }^{29} \mathrm{~N}_{2}-{ }^{28} \mathrm{~N}_{2},{ }^{34} \mathrm{O}_{2}{ }^{32} \mathrm{O}_{2}$ and ${ }^{36} \mathrm{Ar}-{ }^{40} \mathrm{Ar}$ at $20^{\circ} \mathrm{C}$ are about $0.0045,0.0099$ and -0.0137 , respectively (Lang, 1999). The expected correlation slopes for thermal diffusion obtained from these diffusion factors are shown as grey lines in Fig. 5. Measurements of the isotopic composition of $\mathrm{N}_{2}, \mathrm{O}_{2}$ and Ar are further discussed in Sect. 3.4.

Experiments showed that the thermal fractionation at the intake could be reduced if instead of Dekabon other types of tubing are used. Intakes both made of transparent plastic and stainless steel significantly reduced this effect, presumably because of a smaller influence of solar heating. However, thermal fractionation could also be observed on days with overcast sky. Shading of the intake from sunlight can therefore only reduce but not eliminate this effect. High flow velocities at the intake either by large sampling flows or by intake tubes with small inner diameters may be most helpful for reducing thermal diffusion at the intake. Additional tests with sample air from a high pressure cylinder showed that there is also a measurable influence of the laboratory temperature on $\delta \operatorname{Ar} / \mathrm{N}_{2}$. A cylinder was placed outside the laboratory where only small and not abrupt temperature variations occur to exclude any fractionation related to the cylinder or the pressure regulator. Then, the measured $\delta \mathrm{Ar} / \mathrm{N}_{2}$ showed to be positively correlated with the laboratory temperature (in contrast to the negative temperature sensitivity for fractionation at the intake). Different sources of thermal fractionation inside the laboratory may lead to these effects: a) The cold trap which is partly immersed in silicon oil at $-70^{\circ} \mathrm{C}$. Because of the relatively large volume $(\sim 250 \mathrm{~mL})$ and the large temperature gradient $\left(\sim 90^{\circ} \mathrm{C}\right)$ thermal diffusion is likely to occur inside this cold trap. Changing temperature gradients due to varying room temperatures could therefore lead to thermal effects. b) Temperature dependent fractionation at tees (Manning, 2001), and c) Fluctuations of the working gas due to thermally induced effects at the highpressure gas cylinders. We favor explanation $b$ ) based on first tests of divided air fluxes by tees showing a clear thermal diffusion effect.

\subsection{The $\mathrm{CO}_{2}$ record}

The prevalent local wind directions are the northern and western wind sector. High wind speeds occur with winds coming from north-east to east $\left(45\right.$ to $\left.90^{\circ}\right)$ and from west to south-west $\left(225\right.$ to $270^{\circ}$ ), which are the predominant mesoscale wind directions on the Swiss Plateau. Generally, there is a good correlation between $\mathrm{CO}_{2}$ and ${ }^{222} \mathrm{Rn}$ for all wind directions. Also, no significant correlation between wind direction and $\mathrm{CO}_{2}$ mixing ratio was found, indicating that no distinct $\mathrm{CO}_{2}$ sources are in the immediate vicinity of the sampling site.

An overview of atmospheric records of $\mathrm{CO}_{2},{ }^{222} \mathrm{Rn}$, $\mathrm{O}_{2} / \mathrm{N}_{2}, \delta^{13} \mathrm{C}$ and $\delta^{18} \mathrm{O}$ of $\mathrm{CO}_{2}$ at Bern between October 2003 and February 2005 is given in Fig. 6. The diurnal variability is much larger than the seasonal variability and is mainly caused by local sources and sinks and by diurnal changes of atmospheric mixing conditions in the boundary layer. 


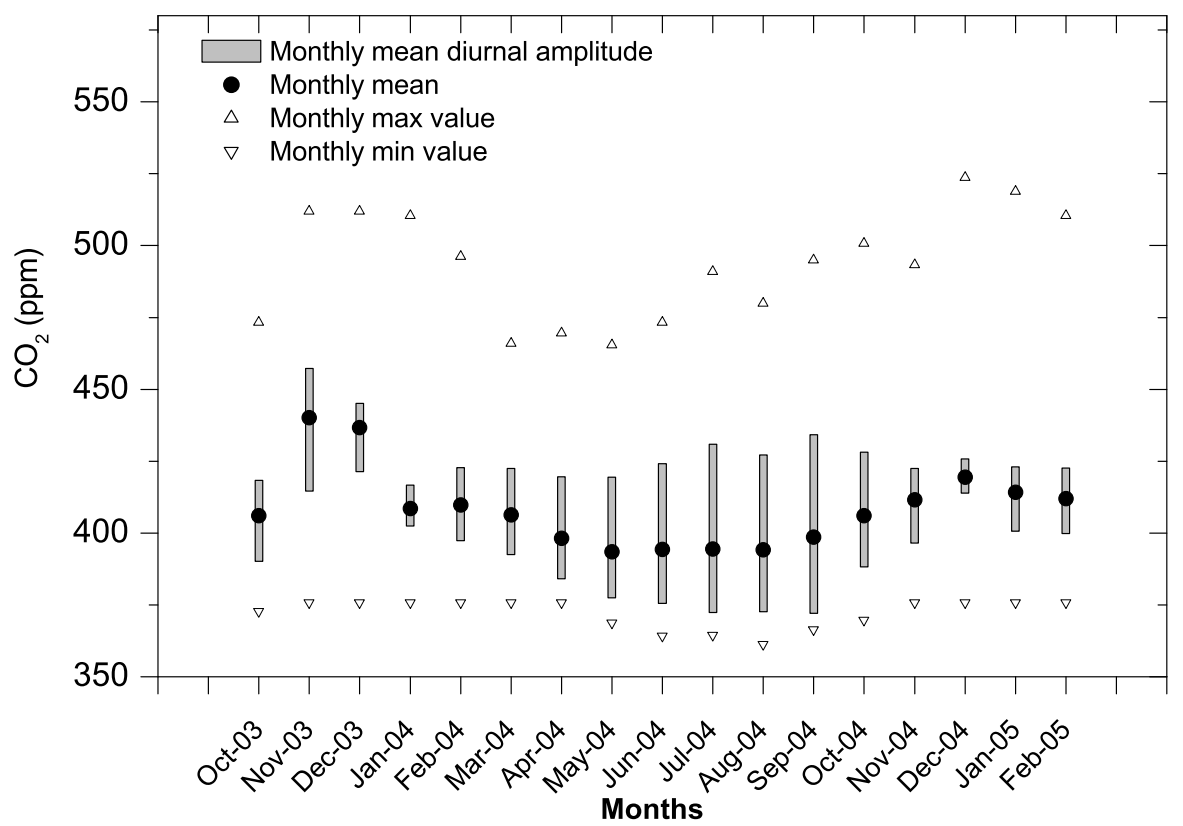

Fig. 7. Monthly mean diurnal amplitudes (columns), monthly mean (black circles) and monthly maximum and minimum (triangles) of $\mathrm{CO}_{2}$ for the months October 2003 to February 2005.

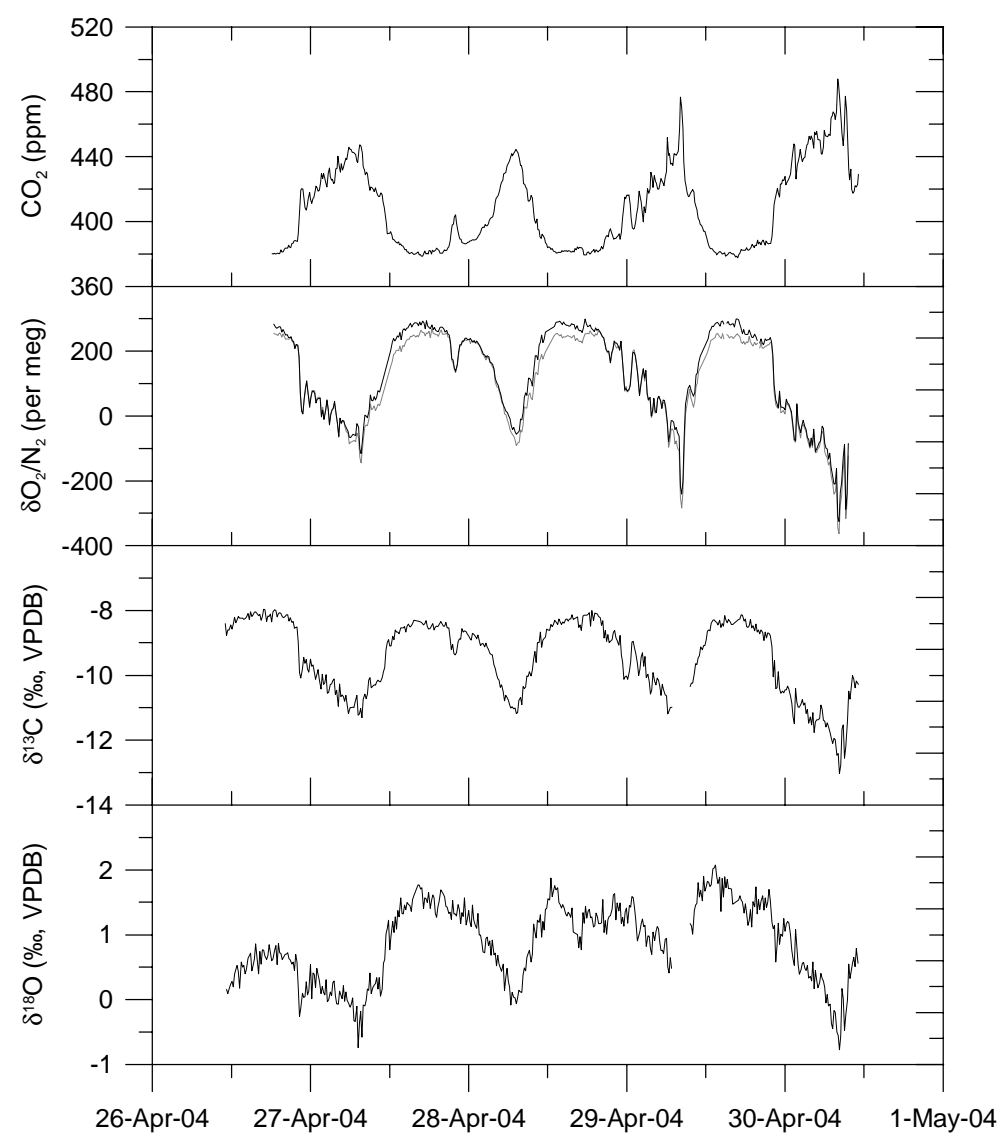

Fig. 8. Example of continuous $\mathrm{CO}_{2}, \mathrm{O}_{2} / \mathrm{N}_{2}, \delta^{13} \mathrm{C}$ and $\delta^{18} \mathrm{O}$ records between 26 April and 1 May 2004. For the $\mathrm{O}_{2} / \mathrm{N}_{2}$ the original (shaded line) as well as the corrected values (black line) are shown (see text for explanation). 

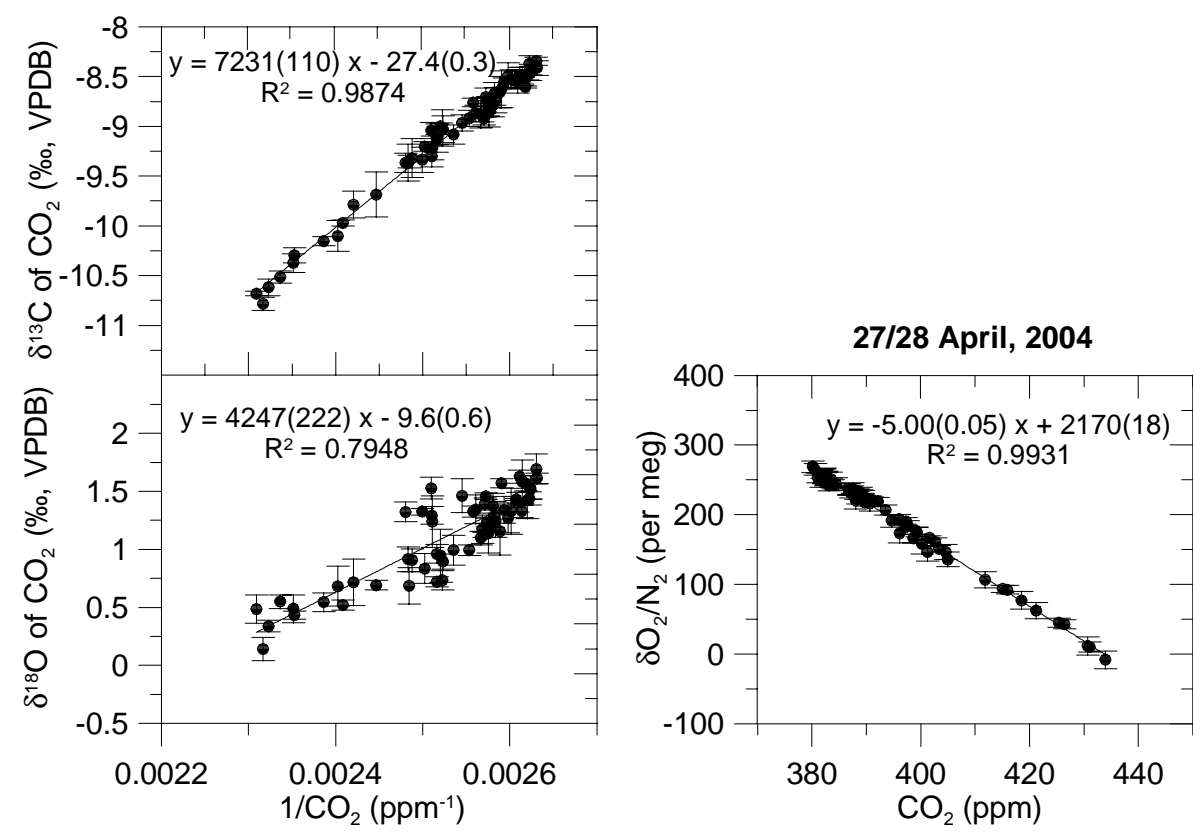

Fig. 9. Representative Keeling plot of carbon and oxygen isotope ratios and $\delta \mathrm{O}_{2} / \mathrm{N}_{2}-\mathrm{CO}_{2}$ correlation during the night (18:00 to 06:00 LT) of $27 / 28$ April 2004. Note that variations in $\delta \mathrm{O}_{2} / \mathrm{N}_{2}$ correspond mainly to variations in $\mathrm{O}_{2}$ (see text). The equations shown are derived from geometric mean regression (uncertainty in parentheses).

$\mathrm{CO}_{2}$ mixing ratios were highest in the wintertime with nighttime maximum values reaching more than $500 \mathrm{ppm}$. During atmospheric inversion events, characterized by persistent fog in autumn and winter, the $\mathrm{CO}_{2}$ mixing ratio was clearly above $400 \mathrm{ppm}$ over a period of several days. Afternoon values in the spring and summer were commonly close to the background value as measured for example at Jungfraujoch (Sturm et al., 2005b). Figure 7 shows the monthly mean diurnal amplitudes and the monthly mean of the $\mathrm{CO}_{2}$ mixing ratio for the months October 2003 to February 2005. Diurnal variations of $\mathrm{CO}_{2}$ show a minimum in the afternoon followed by an increase towards the maximum in the early morning hours. The diurnal $\mathrm{CO}_{2}$ amplitudes are largest in summer (55 to $60 \mathrm{ppm}$ peak-to-peak) and smallest in winter ( 15 to 25 ppm peak-to-peak) but the monthly amplitudes (i.e. the difference between the monthly maximum and the monthly minimum) are smallest in summer (118 to $128 \mathrm{ppm}$ peak-to-peak) and largest in winter (120 to $148 \mathrm{ppm}$ peak-to-peak) due to inversion events as mentioned above.

\section{$3.3 \delta^{13} \mathrm{C}$ of $\mathrm{CO}_{2}, \delta^{18} \mathrm{O}$ of $\mathrm{CO}_{2}$ and $\mathrm{O}_{2} / \mathrm{N}_{2}$ measurements}

Isotopic and elemental ratios could only be measured periodically, at times when no other applications and measurements were run on the analyzers. This results in larger gaps in these records compared to the $\mathrm{CO}_{2}$ record (Fig 6). Figure 8 shows an example for typical diurnal cycles of $\mathrm{CO}_{2}$, $\mathrm{O}_{2} / \mathrm{N}_{2}, \delta^{13} \mathrm{C}$ and $\delta^{18} \mathrm{O}$ records between 26 April and 1 May 2004. The $\mathrm{O}_{2} / \mathrm{N}_{2}, \delta^{13} \mathrm{C}$ and $\delta^{18} \mathrm{O}$ measurements mirror the
$\mathrm{CO}_{2}$ variations. The influence of thermal fractionation on $\mathrm{O}_{2} / \mathrm{N}_{2}$ was corrected using the $\delta \mathrm{Ar} / \mathrm{N}_{2}$ measurements as follows. In a first step, the biogenic and anthropogenic components of $\mathrm{O}_{2} / \mathrm{N}_{2}$ variations were removed by subtracting the $\mathrm{CO}_{2}$ record scaled by the observed $\mathrm{O}_{2}: \mathrm{CO}_{2}$ ratio. Variations in the residual $\mathrm{O}_{2} / \mathrm{N}_{2}$ are then expected to represent thermal fractionation effects. Secondly, the fractionation ratio of $\mathrm{O}_{2} / \mathrm{N}_{2}$ and $\delta \mathrm{Ar} / \mathrm{N}_{2}$ was determined by the correlation between the residual $\mathrm{O}_{2} / \mathrm{N}_{2}$ and $\delta \mathrm{Ar} / \mathrm{N}_{2}$. The slope of this correlation varies between 3.9 and $1.7\left(R^{2}=0.8\right.$ to 0.4$)$, which either reflects mixed influences of laboratory and outdoor temperature fractionation or different flow conditions in the inlet system depending on the measurement setup. With this $\mathrm{O}_{2} / \mathrm{N}_{2}-\mathrm{Ar} / \mathrm{N}_{2}$ fractionation ratio, the $\delta \mathrm{Ar} / \mathrm{N}_{2}$ variations are then used to finally subtract the thermally induced $\mathrm{O}_{2} / \mathrm{N}_{2}$ variations from the original $\mathrm{O}_{2} / \mathrm{N}_{2}$ to obtain the corrected $\mathrm{O}_{2} / \mathrm{N}_{2}$. In Fig. 8 the original (shaded line) as well as the corrected $\mathrm{O}_{2} / \mathrm{N}_{2}$ (black line) are shown. The correction is less than $5 \%$ of the measured $\mathrm{O}_{2} / \mathrm{N}_{2}$ signal.

A representative Keeling plot of $\delta^{13} \mathrm{C}$ and $\delta^{18} \mathrm{O}$ (Keeling, $1958,1961)$ and the corresponding $\delta \mathrm{O}_{2} / \mathrm{N}_{2}-\mathrm{CO}_{2}$ correlation during the night of 27/28 April 2004 is shown in Fig. 9. Note that variations in $\delta \mathrm{O}_{2} / \mathrm{N}_{2}$ mirror mainly oxygen variations since atmospheric nitrogen remains nearly constant, except changes due to the seasonal temperature induced variability of the ocean solubility. Only nighttime values (18:00 to $06: 00 \mathrm{LT}$ ) have been used to match the Keeling plot assumptions, i.e., a constant background $\mathrm{CO}_{2}$ concentration and a constant isotopic signature of the source or sink, as 


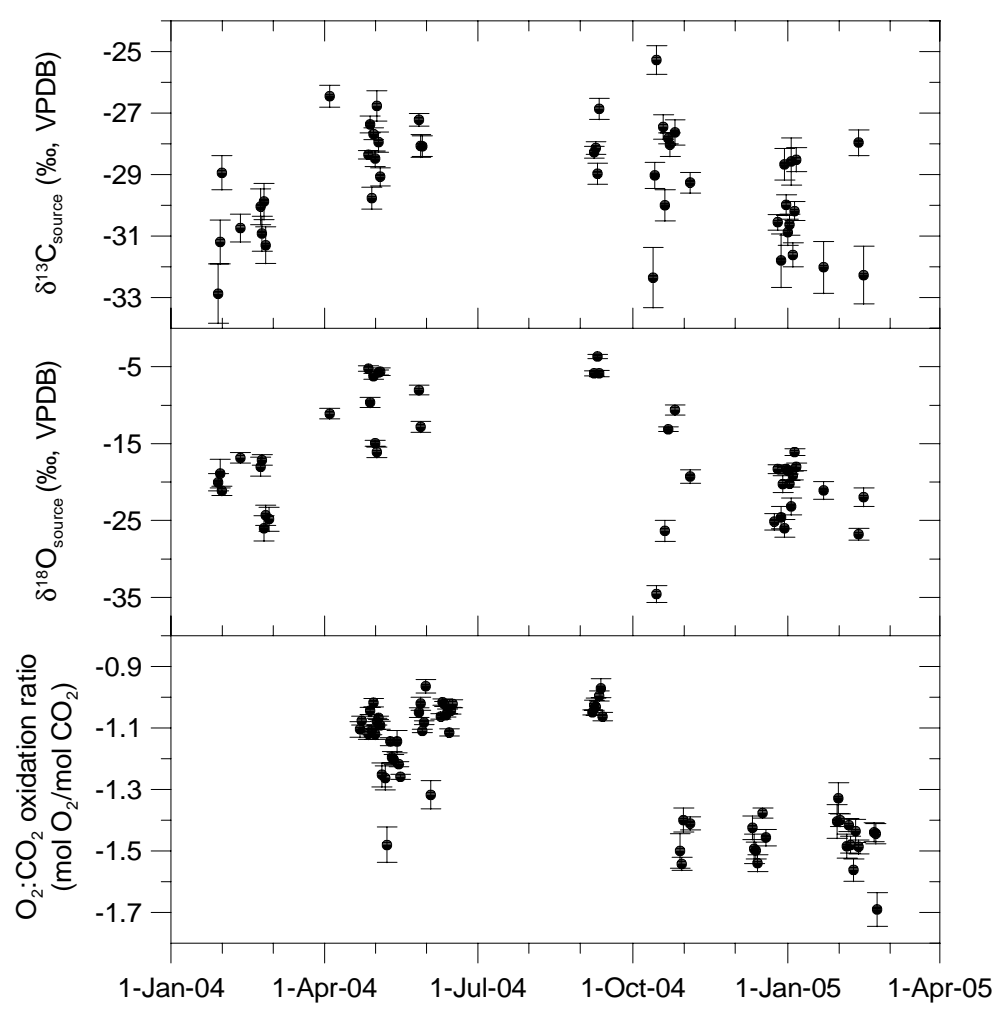

Fig. 10. $\delta^{13} \mathrm{C}$ and $\delta^{18} \mathrm{O}$ of source $\mathrm{CO}_{2}$ calculated from Keeling plots, and $\mathrm{O}_{2}: \mathrm{CO}_{2}$ oxidation ratios.

accurately as possible. Still, the $\delta^{13} \mathrm{C}_{\text {source }}, \delta^{18} \mathrm{O}_{\text {source }}$ and $\mathrm{O}_{2}: \mathrm{CO}_{2}$ ratios mostly represent a flux weighted average of more than one source and/or sink. Varying proportions of $\mathrm{CO}_{2}$ sources containing distinct isotope ratios violate the assumptions of the 2-ended mixing model, and are more common with oxygen than carbon isotopes, causing poorer relationships between $\delta^{18} \mathrm{O}$ and $1 / \mathrm{CO}_{2}$. In Fig. 10 the nighttime buildup of $\mathrm{CO}_{2}$ was used to derive daily values of $\delta^{13} \mathrm{C}_{\text {source }}$, $\delta^{18} \mathrm{O}_{\text {source }}$ and $\mathrm{O}_{2}: \mathrm{CO}_{2}$ by the Keeling plot intercept method. The correlations were calculated by geometric mean regression and error bars are the standard deviation of the slopes. Only nights with more than 25 measurements, correlation coefficients larger than $R^{2}=0.9$ for $\delta^{13} \mathrm{C}$ and $\mathrm{O}_{2}: \mathrm{CO}_{2}$ and larger than $R^{2}=0.7$ for $\delta^{18} \mathrm{O}$ were considered. The nighttime $\delta^{13} \mathrm{C}_{\text {source }}$ varies between $-33 \%$ and $-25 \%$ with generally lower values in the winter months than during the rest of the year. This likely represents the larger influence of fossil fuel combustion in wintertime. The large variability from one night to the next may be caused by different weather conditions resulting in advection of different air masses or changes in the $\mathrm{CO}_{2}$ source distribution. A similar picture can be seen for the nighttime $\delta^{18} \mathrm{O}_{\text {source. }}$. The values range from $-34 \%$ o to $-3 \%$ o with the depleted (more negative) signatures again occurring in wintertime and highly enriched (more positive) values in spring and summer. This seasonal variation of $\delta^{18} \mathrm{O}_{\text {source }}$ is somewhat larger than the variations of about $-21 \%$ o to $-11 \%$ o observed by Pataki et al. (2003) in a similar study. The $\delta^{18} \mathrm{O}$ signal of atmospheric $\mathrm{CO}_{2}$ is a signal dominated by $\mathrm{CO}_{2}$ exchange with the terrestrial biosphere (Ciais et al., 1997a,b; Keeling, 1995). Fractionation of the oxygen isotopes of $\mathrm{CO}_{2}$ occurs in plants owing to differential diffusion of $\mathrm{C}^{18} \mathrm{O}^{16} \mathrm{O}$ and $\mathrm{C}^{16} \mathrm{O}^{16} \mathrm{O}$ and to isotope effects in oxygen exchange with chloroplast water. The higher $\delta^{18} \mathrm{O}$ values in summer compared to winter are most probably caused by strong photosynthetic activity and an associated exchange of ${ }^{18} \mathrm{O}$ with leaf water in plants, which is generally enriched in $\delta^{18} \mathrm{O}$ if compared to the ground water due to evapotranspiration (Dongmann et al., 1974). Furthermore, $\mathrm{CO}_{2}$ from combustion has a $\delta^{18} \mathrm{O}$ value similar to the $\delta^{18} \mathrm{O}$ of atmospheric $\mathrm{O}_{2}$ at $-18 \%$ on the VPDB- $\mathrm{CO}_{2}$ scale, corresponding to $23.5 \%$ on the SMOW scale (Kroopnick and Craig, 1972). Thus a larger fossil fuel $\mathrm{CO}_{2}$ component in winter leads to decreased $\delta^{18} \mathrm{O}$ values.

For a possible interpretation of the observed $\mathrm{O}_{2}: \mathrm{CO}_{2}$ ratios we consider a simple model. If we assume that the diurnal variations can be described by biogenic and fossil fuel fluxes of carbon and oxygen in the catchment area of the sampling site, then the atmospheric mass balance for $\mathrm{CO}_{2}$ and $\mathrm{O}_{2}$ can be written

$\Delta \mathrm{CO}_{2}=F+B$

and

$\Delta \mathrm{O}_{2}=\alpha_{F} F+\alpha_{B} B$, 
where $\Delta \mathrm{CO}_{2}$ and $\Delta \mathrm{O}_{2}$ are the observed changes in the atmospheric $\mathrm{CO}_{2}$ and $\mathrm{O}_{2}$ concentration, $F$ and $B$ are the fluxes of carbon to the atmosphere due to fossil fuel combustion and the terrestrial biosphere, respectively (positive for release to the atmosphere). The coefficients $\alpha_{F}$ and $\alpha_{B}$ are average $\mathrm{O}_{2}: \mathrm{CO}_{2}$ exchange ratios for fossil fuel and land biota. We use $\alpha_{F}=-1.4 \mathrm{~mol} \mathrm{O}_{2} / \mathrm{mol} \mathrm{CO}_{2}$ (Manning, 2001) and $\alpha_{B}=-1.1 \mathrm{~mol} \mathrm{O}_{2} / \mathrm{mol} \mathrm{CO}_{2}$ (Severinghaus, 1995). By combining Eqs. (1) and (2) and assuming that $F$ and $B$ are constant over the considered time period, we can estimate from the observed $\mathrm{O}_{2}: \mathrm{CO}_{2}$ exchange ratio $\left(\Delta \mathrm{O}_{2} / \Delta \mathrm{CO}_{2}\right)$ the proportion of the biogenic flux in relation to the fossil fuel flux

$$
\frac{B}{F}=-\frac{\Delta \mathrm{O}_{2} / \Delta \mathrm{CO}_{2}-\alpha_{F}}{\Delta \mathrm{O}_{2} / \Delta \mathrm{CO}_{2}-\alpha_{B}} .
$$

The measured nighttime $\mathrm{O}_{2}: \mathrm{CO}_{2}$ oxidation ratios from April 2004 to February 2005 are between -0.96 and -1.69 (lowest panel in Fig. 10). For nighttime air sampling it is assumed that respired $\mathrm{CO}_{2}$ is added to the atmosphere and both fluxes $F$ and $B$ are positive. This would lead to $\mathrm{O}_{2}: \mathrm{CO}_{2}$ ratios between -1.1 and -1.4 . However, almost half of the summer values are between -0.96 and -1.1 . This could only be explained with a biogenic $\mathrm{CO}_{2}$ sink up to four times as strong as the fossil fuel source, which is obviously not the case, since the $\mathrm{CO}_{2}$ concentration is increasing and not decreasing during the night. The same considerations can also be applied to the $\delta^{13} \mathrm{C}_{\text {source }}$ data, where no conflicting picture can be seen. The measured $\delta^{13} \mathrm{C}_{\text {source }}$ are in the range between an assumed $\delta^{13} \mathrm{C}$ of the biospheric component of about $-26 \%$ and the more depleted values of the fossil fuel component. One possibility to explain these low $\mathrm{O}_{2}: \mathrm{CO}_{2}$ ratios would be an overestimation of the span of our $\mathrm{CO}_{2}$ scale by more than $10 \%$. Comparison of our $\mathrm{CO}_{2}$ data with $\mathrm{CO}_{2}$ measurements from Laboratoire des Science du Climat et de l'Environnement, CE Saclay, France, (Sturm et al., 2005a) and our internal measurements of the calibrated NOAA $\mathrm{CO}_{2}$ standards on the WMO $\mathrm{CO}_{2}$ scale lead to the conclusion that this is highly unlikely. An underestimation of the $\mathrm{O}_{2} / \mathrm{N}_{2}$ span of this magnitude can not be ruled out a priori, though. Since international intercomparison programs for $\mathrm{O}_{2} / \mathrm{N}_{2}$ measurements are being initiated only now, we do not have any independent validation of our $\mathrm{O}_{2} / \mathrm{N}_{2}$ scale yet. Measurement effects related to the mass spectrometric technique like cross contamination (Meijer et al., 2000) could potentially lead to an underestimation of the $\mathrm{O}_{2} / \mathrm{N}_{2}$ span. However, no such effects have been reported by other laboratories also measuring $\mathrm{O}_{2} / \mathrm{N}_{2}$ by mass spectrometry so far. Another alternative to explain the observed $\mathrm{O}_{2}: \mathrm{CO}_{2}$ ratios is that processes with $\mathrm{O}_{2}: \mathrm{CO}_{2}$ exchange ratios of about -1.0 play a major role in nighttime build-up of $\mathrm{CO}_{2}$. Stephens et al. (2001) have also reported on $\mathrm{O}_{2}: \mathrm{CO}_{2}$ relationships that are considerably smaller than theory would suggest, but potential atmospheric or physiological origins for such relationships are unknown.

\section{$3.4 \delta^{29} \mathrm{~N}_{2}, \delta^{34} \mathrm{O}_{2}$ and $\delta^{36} \mathrm{Ar}$ of air}

Measurements of the isotopic composition of $\mathrm{N}_{2}, \mathrm{O}_{2}$ and $\mathrm{Ar}$ are shown in Fig. 11. These isotopic ratios are as a first approximation constant within measurement precision during the observation period of almost one year. Measurement precision is largely represented by the range of the short-term variations in these records. The small long-term variations of the mean appearing in Fig. 11 are due to changes in mass spectrometer performance. Owing to the relatively high sampling rate of 5 measurements per hour, there are also diurnal variations detectable. However, because of the many gaps in the available record and the poor signal-to-noise ratio it is difficult to quantify these effects. As already mentioned in Sect. 3.1, thermal diffusion fractionation at the air intake is considered to be the dominant cause for such diurnal variations. An assumed variation in $\delta \mathrm{Ar} / \mathrm{N}_{2}$ of 200 per meg due to thermal diffusion would correspond to variations in $\delta^{29} \mathrm{~N}_{2}, \delta^{34} \mathrm{O}_{2}$ and $\delta^{36} \mathrm{Ar}$ of about 13,28 and 39 per meg, respectively. This might be consistent with the observed diurnal variations for $\delta^{29} \mathrm{~N}_{2}$ and $\delta^{34} \mathrm{O}_{2}$. For $\delta^{36} \mathrm{Ar}$ the measured amplitude of the variations seems to be larger (about 150 per meg) than what is expected from thermal fractionation, thus $\delta^{36} \mathrm{Ar}$ is probably also influenced by other unidentified measurement artifacts.

The $\delta^{18} \mathrm{O}$ of atmospheric $\mathrm{O}_{2}\left(\delta^{34} \mathrm{O}_{2}\right)$ is affected by photosynthesis and respiration in the carbon/oxygen cycle and by the hydrological cycle, similar to the oxygen isotopic composition of $\mathrm{CO}_{2}$. Could we potentially detect biogeochemical variations of $\delta^{18} \mathrm{O}$ of atmospheric $\mathrm{O}_{2}$ in our record? The $\delta^{18} \mathrm{O}$ of atmospheric oxygen is enriched by 23.5\% relative to average ocean water (Kroopnick and Craig, 1972), which is known as the Dole effect. The $\delta^{18} \mathrm{O}$ produced by photosynthesis is similar to that of the water from which the oxygen isotopes originate, whereas respiration fractionates by about $-20 \%$ relative to atmospheric $\mathrm{O}_{2}$ (Guy et al., 1993). The $\delta^{18} \mathrm{O}$ of leaf water is elevated by 4 to $8 \%$ o compared to oceanic water due to evapotranspiration (Dongmann, 1974; Farquhar et al., 1993). If we assume that a diurnal increase in atmospheric $\mathrm{O}_{2} / \mathrm{N}_{2}$ of 500 per meg is driven by the input of photosynthetic $\mathrm{O}_{2}$ that is about $20 \%$ o lower in $\delta^{18} \mathrm{O}$ than atmospheric $\mathrm{O}_{2}$, we would expect a change in $\delta^{18} \mathrm{O}$ of $\mathrm{O}_{2}$ of 10 per meg. The seasonal variability of $\mathrm{O}_{2} / \mathrm{N}_{2}(\sim 150$ per meg) leads to an even smaller signal in $\delta^{18} \mathrm{O}$ of $\mathrm{O}_{2}(\sim 3$ per meg). The measurement precision defined as the standard deviation of a single measurement is about 40 per meg for $\delta^{34} \mathrm{O}_{2}$. Thus, detecting such small variations is very difficult with current mass spectrometric measurements.

\section{$3.5{ }^{222} \mathrm{Rn}$ tracer method to estimate regional $\mathrm{CO}_{2}$ emis- sions}

The ${ }^{222} \mathrm{Rn}$ activity was measured during a three month period between 27 January and 26 April 2004 . The specific activity 


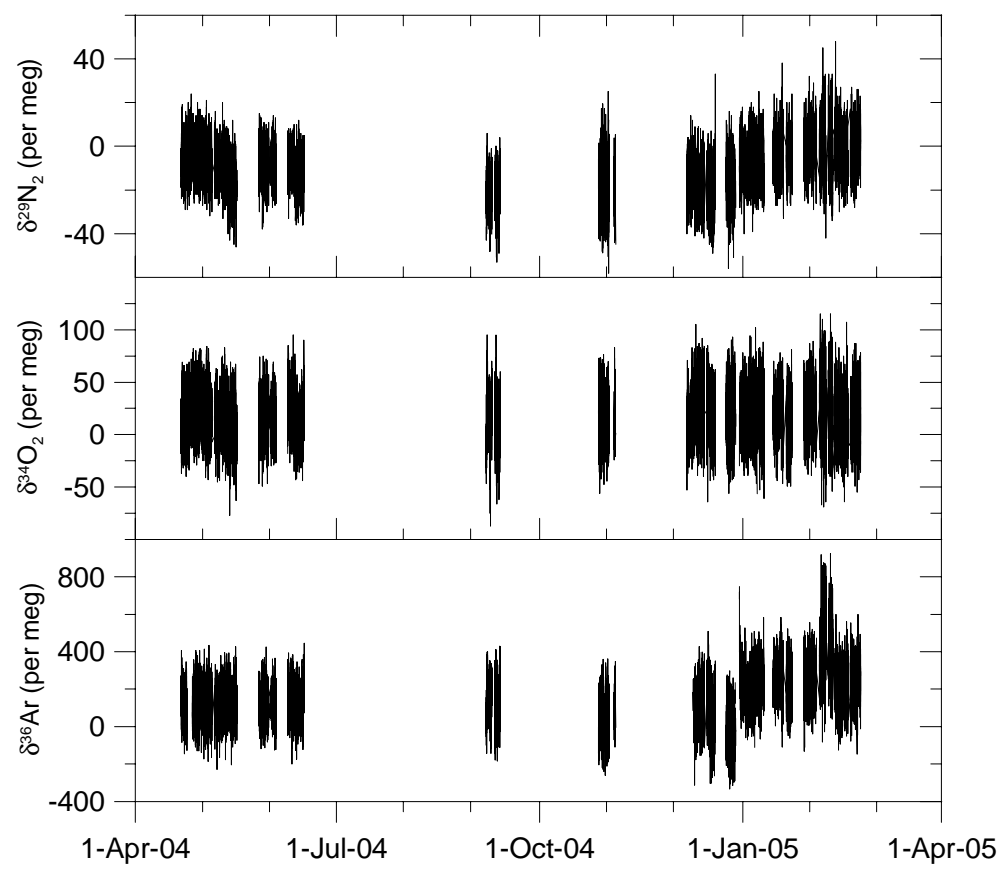

Fig. 11. Measurements of the isotopic ratios $\delta^{29} \mathrm{~N}_{2}, \delta^{34} \mathrm{O}_{2}$ and $\delta^{36}$ Ar at Bern between April 2004 and February 2005.

ranged from 0 to $20 \mathrm{~Bq} \mathrm{~m}^{-3}$ (Fig. 6). Examples of hourly mean values of $\mathrm{CO}_{2}$ and ${ }^{222} \mathrm{Rn}$, together with local wind speed and wind direction between 17 and 23 March 2004 and between 1 and 7 April 2004 are shown in Fig. 12. During the first days of these periods wind speeds are low with frequently changing directions. The trace gas concentration records show a typical diurnal pattern caused by nighttime inversion situations. On 19 March and 4 April, respectively, winds change to westerly directions with persistently high wind speeds. The $\mathrm{CO}_{2}$ and ${ }^{222} \mathrm{Rn}$ concentrations are then close to continental background levels (Schmidt et al., 1996). The correlation between ${ }^{222} \mathrm{Rn}$ and $\mathrm{CO}_{2}$ will be used to estimate $\mathrm{CO}_{2}$ fluxes for the catchment area of the sampling site.

The ${ }^{222} \mathrm{Rn}$ measurements can be used to infer $\mathrm{CO}_{2}$ emission by using a simple 1-D approach. This method has been used for other greenhouse gases and at different sites and is described in detail by Schmidt et al. (2001). Assuming that each trace gas is released to the atmosphere at a constant rate $\bar{j}_{i}$ and that it accumulates in a well-mixed boundary layer of height $H(t)$, the short-term change in concentration $\Delta c_{i}(t)$ is then:

$$
\frac{\Delta c_{i}(t)}{\Delta t}=\frac{\bar{j}_{i}}{H(t)}
$$

Since $H(t)$ is the same for ${ }^{222} \mathrm{Rn}$ and $\mathrm{CO}_{2}$, we can eliminate $H(t)$ by combining both tracers

$\bar{j}_{\mathrm{CO}_{2}}=\bar{j}_{\mathrm{Rn}} \frac{\Delta c_{\mathrm{CO}_{2}}}{\Delta c_{\mathrm{Rn}}}$.

The $\mathrm{CO}_{2}$ flux can thus be calculated from the measured slope between $\mathrm{CO}_{2}$ and ${ }^{222} \mathrm{Rn}$ variations and the ${ }^{222} \mathrm{Rn}$ exhalation rate. The radioactive decay of ${ }^{222} \mathrm{Rn}$ in the atmosphere during a typical nighttime inversion situation lasting about $12 \mathrm{~h}$ leads to a net ${ }^{222} \mathrm{Rn}$ loss of about $5 \%$. Therefore a mean correction factor of 0.95 is applied when estimating ${ }^{222} \mathrm{Rn}$-based $\mathrm{CO}_{2}$ fluxes.

Daily $\mathrm{CO}_{2} / 222 \mathrm{Rn}$ correlations were determined using geometric mean regression. To derive a mean value for the period from February to April 2004 only those days were included for which more than 12 hourly mean values existed and which showed a correlation coefficient larger than $R^{2}=0.4$. 33 days $(39 \%)$ satisfy this criterion. The mean $\mathrm{CO}_{2} /{ }^{222} \mathrm{Rn}$ slope is $5.2 \pm 1.7 \mathrm{ppm} / \mathrm{Bq} \mathrm{m}^{-3}$. This is larger than estimates from other European sites. Schmidt et al. (1996) have measured $\mathrm{CO}_{2}{ }^{222} \mathrm{Rn}$ slopes at Schauinsland, Germany, in the range of 1.8 to $3.5 \mathrm{ppm} / \mathrm{Bq} \mathrm{m}^{-3}$ for the winter months. A wintertime estimation for western $\mathrm{Eu}-$ rope from the Mace Head record by Biraud et al. (2000) gives a slope of 1.4 to $2.1 \mathrm{ppm} / \mathrm{Bq} \mathrm{m}^{-3}$ for all selected events and 4.7 to $6.8 \mathrm{ppm} / \mathrm{Bq} \mathrm{m}^{-3}$ for "polluted" events. The ${ }^{222} \mathrm{Rn}$ flux emitted over continents is not strictly uniform, but depends mainly on the soil type and the hydrological conditions. There is no regional map of observed ${ }^{222} \mathrm{Rn}$ emissions available, but ${ }^{222} \mathrm{Rn}$ flux measurement at different sites in Germany showed an average flux of about $50 \mathrm{~Bq} \mathrm{~m}^{-2} \mathrm{~h}^{-1}$, corresponding to 0.7 atoms $\mathrm{cm}^{-2} \mathrm{~s}^{-1}$ (Dörr and Münnich, 1990; Schmidt et al., 2001). The uncertainty of the ${ }^{222} \mathrm{Rn}$ exhalation rate is estimated as $\pm 25 \%$ (Schmidt et al., 2001). Using this estimation of the ${ }^{222} \mathrm{Rn}$ exhalation rate one obtains a mean $\mathrm{CO}_{2}$ flux density during the period February/March/April 2004 for the Bern region of 

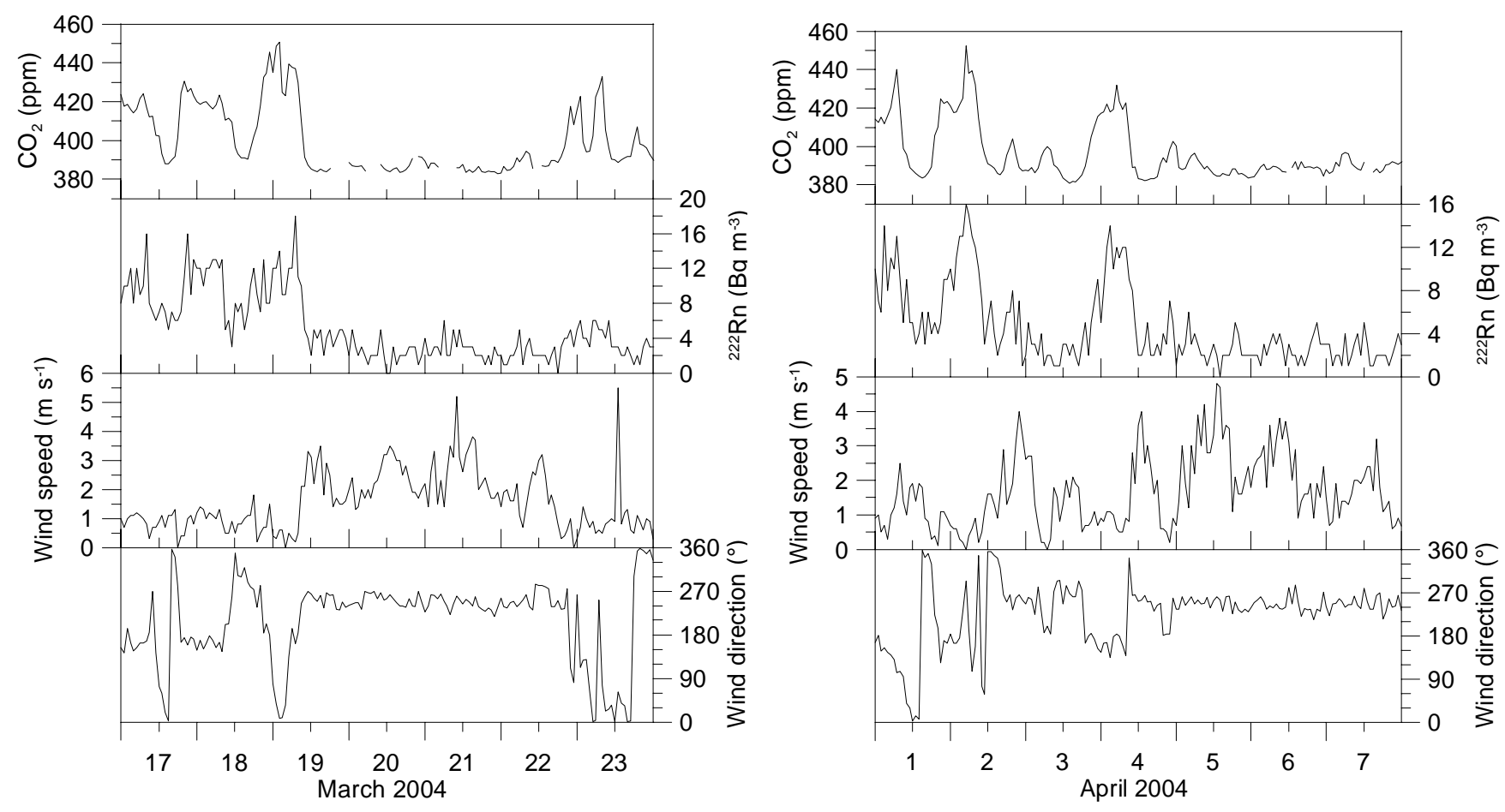

Fig. 12. Examples of hourly mean values of $\mathrm{CO}_{2}$ and ${ }^{222} \mathrm{Rn}$, together with local wind speed and wind direction between 17 and $23 \mathrm{March}$ 2004 (left panel) and between 1 and 7 April 2004 (right panel).

11.0 \pm 4.5 mmole $\mathrm{m}^{-2} \mathrm{~h}^{-1}$ or $95 \pm 39 \mathrm{tC} \mathrm{km}^{-2}$ month $^{-1}$. This $\mathrm{CO}_{2}$ flux includes both biogenic and fossil fuel fluxes. The two main sources of uncertainty for this estimate, namely the ${ }^{222} \mathrm{Rn}$ flux and the $\mathrm{CO}_{2} /{ }^{222} \mathrm{Rn}$ correlation amount to an overall uncertainty of the $\mathrm{CO}_{2}$ flux estimate of $\pm 41 \%$. To reduce this uncertainty the exact source areas of both $\mathrm{CO}_{2}$ and ${ }^{222} \mathrm{Rn}$ should be known. This would require an explicit transport model, which can resolve the spacial and temporal patterns of the $\mathrm{CO}_{2}$ and ${ }^{222} \mathrm{Rn}$ sources.

\section{Summary and outlook}

We summarize first results from on-going continuous measurements of $\mathrm{CO}_{2}$, its stable isotopes and $\mathrm{O}_{2} / \mathrm{N}_{2}$ in Bern. Concurrent $\mathrm{Ar} / \mathrm{N}_{2}$ measurements revealed that diffusive fractionation due to thermal gradients at the air intake is an important modifying process for high precision $\mathrm{O}_{2} / \mathrm{N}_{2}$ measurements. The $\mathrm{CO}_{2}, \mathrm{O}_{2} / \mathrm{N}_{2}, \delta^{13} \mathrm{C}$ and $\delta^{18} \mathrm{O}$ of $\mathrm{CO}_{2}$ data show strong diurnal and seasonal cycles. The diurnal variations are modulated by surface uptake and release by vegetation and soils, emissions from fossil fuel combustion, and by the diurnal development of the atmospheric boundary layer. Both stable carbon and oxygen isotopes showed depletion in the winter and enrichment in the summer due to changes in the proportions of fossil fuel combustion and biogenic respiration at different times of the year. Additionally, ${ }^{222} \mathrm{Rn}$ was used to estimate a mean $\mathrm{CO}_{2}$ flux density in the catchment area of the sampling site. As the measurements go on and more data will become available the $\mathrm{CO}_{2}$ isotope and mixing ratio data can be used to quantify with a mass balance calculation the proportional contribution of each component to the total $\mathrm{CO}_{2}$ source. We also expect to observe interannual variations of the seasonal cycle, and changes in $\mathrm{CO}_{2}$ mixing ratio relative to background sites, such as Jungfraujoch. Comparison of boundary layer mixing ratios with background mixing ratios should help to improve our understanding of atmosphere/surface exchange of $\mathrm{CO}_{2}$ on the continental scale.

Acknowledgements. We thank P. Nyfeler for technical assistance, L. Martin (Institute of Applied Physics, University of Bern, Switzerland) for providing the meteorological data and R. Hesterberg for the $\delta^{13} \mathrm{C}$ and $\delta^{18} \mathrm{O}$ data of Fig. 1. This work was supported by the Swiss National Science Foundation, in particular the R'equip program, and the EU Projects AEROCARB and CARBOEUROPE-IP.

Edited by: U. Baltensperger

\section{References}

Bender, M. L., Tans, P. P., Ellis, T. J., Orchardo, J., and Habfast, $\mathrm{K}$.: A high precision isotope ratio mass spectrometry method for measuring the $\mathrm{O}_{2} / \mathrm{N}_{2}$ ratio of air, Geochim. Cosmochim. Acta, 58, 4751-4758, 1994. 
Biraud, S., Ciais, P., Ramonet, M., Simmonds, P., Kazan, V., Monfray, P., O’Doherty, S., Spain, T. G., and Jennings, G. S.: European greenhouse gas emissions estimated from continuous atmospheric measurements and radon 222 at Mace Head, Ireland, J. Geophys. Res., 105, 1351-1366, 2000.

Chapman, S. and Cowling, T. G.: The Mathematical Theory of Non-Uniform Gases, Cambridge Univ. Press, Cambridge, 1970.

Ciais, P., Denning, A. S., Tans, P. P., Berry, J. A., Randall, D. A., Collatz, G. J., Sellers, P. J., White, J. W. C., Trolier, M., Meijer, H. A. J., Francey, R. J., Monfray, P., and Heimann, M.: A three-dimensional synthesis study of $\delta^{18} \mathrm{O}$ in atmospheric $\mathrm{CO}_{2}$, 1. Surface fluxes, J. Geophys. Res., 102, 5857-5872, 1997a.

Ciais, P., Tans, P. P., Denning, A. S., Francey, R. J., Trolier, M., Meijer, H. A. J., White, J. W. C., Berry, J. A., Randall, D. A., Collatz, G. J., Sellers, P. J., Monfray, P., and Heimann, M.: A three-dimensional synthesis study of $\delta^{18} \mathrm{O}$ in atmospheric $\mathrm{CO}_{2}$, 2. Simulations with the TM2 transport model, J. Geophys. Res., 102, 5873-5883, 1997b.

Coplen, T.: Reporting of stable hydrogen, carbon and oxygen isotopic abundances, Pure and Applied Chemistry, 66, 273-276, 1994.

Dongmann, G.: The contribution of land photosynthesis to the stationary enrichment of ${ }^{18} \mathrm{O}$ in the atmosphere, Radiat. Environ. Biophys., 11, 219-225, 1974.

Dongmann, G., Nürnberg, H. W., Förstel, H., and Wagner, K.: On the enrichment of $\mathrm{H}_{2}^{18} \mathrm{O}$ in the leaves of transpiring plants, Radiat. Environ. Biophys., 11, 41-52, 1974.

Dörr, H. and Münnich, K. O.: ${ }^{222} \mathrm{Rn}$ flux and soil air concentration profiles in West-Germany. Soil ${ }^{222} \mathrm{Rn}$ as tracer for gas transport in the unsaturated soil zone, Tellus, 42B, 20-28, 1990.

Farquhar, G. D., Lloyd, J., Taylor, J. A., Flanagnan, L. B., Syvertsen, J. P., Hubick, K. T., Wong, S. C., and Ehleringer, J. R.: Vegetation effects on the isotope composition of oxygen in atmospheric $\mathrm{CO}_{2}$, Nature, 363, 439-443, 1993.

Friedli, H., Siegenthaler, U., Rauber, D., and Oeschger, H.: Measurements of concentration, ${ }^{13} \mathrm{C} /{ }^{12} \mathrm{C}$ and ${ }^{18} \mathrm{O} /{ }^{16} \mathrm{O}$ ratios of tropospheric carbon dioxide over Switzerland, Tellus, 39B, 80-88, 1987.

Fuller, W. A.: Measurement Error Models, Wiley Series in Probability and Statistics, John Wiley \& Sons, New York, 1987.

Gemery, P. A., Trolier, M., and White, J. W. C.: Oxygen isotope exchange between carbon dioxide and water following atmospheric sampling using glass flasks, J. Geophys. Res., 101, 14 415-14 420, 1996.

Grew, K. E. and Ibbs, T. L.: Thermal Diffusion in Gases, Cambridge Univ. Press, Cambridge, 1952.

Guy, R. D., Fogel, M. L., and Berry, J. A.: Photosynthetic Fractionation of the Stable Isotopes of Oxygen and Carbon, Plant Physiol., 101, 37-47, 1993.

Hesterberg, R.: Das Kohlendioxid und seine stabilen Isotope in Atmosphäre und Boden, Master's thesis, Physics Institute, University of Bern, Bern, Switzerland, 1990.

I.A.E.A.: Reference and intercomparison materials for stable isotopes of light elements, IAEA, Vienna, 1995.

Keeling, C. D.: The concentration and isotopic abundances of atmospheric carbon dioxide in rural areas, Geochim. Cosmochim. Acta, 13, 322-334, 1958.

Keeling, C. D.: The concentration and isotopic abundances of carbon dioxide in rural and marine air, Geochim. Cosmochim. Acta,
24, 277-298, 1961.

Keeling, C. D., Bacastow, R. B., Carter, A. F., Piper, S. C., Whorf, T. P., Heimann, M., Mook, W. G., and Roeloffzen, H.: A threedimensional model of atmospheric $\mathrm{CO}_{2}$ transport based on observed winds: 1. Analysis of observational data, in: Aspects of Climate Variability in the Pacific and the Western Americas, edited by: Peterson, D. H., Geophys. Monogr. Ser., 55, 165-236, AGU, Washington D.C., 1989.

Keeling, R.: The atmospheric oxygen cycle: The oxygen isotopes of atmospheric $\mathrm{CO}_{2}$ and $\mathrm{O}_{2}$ and the $\mathrm{O}_{2} / \mathrm{N}_{2}$ ratio, Rev. Geophys., Supplement, 1253-1262, 1995.

Keeling, R. F., Stephens, B. B., Najjar, R. G., Doney, S. C., Archer, D., and Heimann, M.: Seasonal variations in the atmospheric $\mathrm{O}_{2} / \mathrm{N}_{2}$ ratio in relation to the kinetics of air-sea gas exchange, Global Biogeochem. Cycles, 12, 141-163, 1998.

Keeling, R. F., Blaine, T., Paplawsky, B., Katz, L., Atwood, C., and Brockwell, T.: Measurement of changes in atmospheric $\mathrm{Ar} / \mathrm{N}_{2}$ ratio using a rapid-switching, single-capillary mass spectrometer system, Tellus, 56B, 322-338, 2004.

Kroopnick, P. and Craig, H.: Atmospheric Oxygen: Isotopic Composition and Solubility Fractionation, Science, 175, 54-55, 1972.

Lang, C.: Bestimmung und Interpretation der Isotopen- und Elementverhältnisse von Luft aus polaren und alpinen Eisbohrkernen, insbesondere zur Temperaturrekonstruktion unter Ausnutzung des Effekts der Thermodiffusion, $\mathrm{PhD}$ thesis, Physics Institute, University of Bern, Bern, Switzerland, 1999.

Langenfelds, R. L.: Studies of the global carbon cycle using atmospheric oxygen and associated tracers, $\mathrm{PhD}$ thesis, Univ. of Tasmania, Hobart, Tasmania, Australia, 2002.

Lehmann, B. E., Ihly, B., Salzmann, S., Conen, F., and Simon, E.: An automatic static chamber for continuous ${ }^{220} \mathrm{Rn}$ and ${ }^{222} \mathrm{Rn}$ flux measurements from soil, Radiation Measurements, 38, 4350, 2004.

Leuenberger, M., Nyfeler, P., Moret, H. P., Sturm, P., and Huber, C.: A new gas inlet system for an isotope ratio mass spectrometer improves reproducibility, Rapid Commun. Mass Spectrom., 14, 1543-1551, 2000.

Leuenberger, M., Eyer, M., Nyfeler, P., Stauffer, B., and Stocker, T. F.: High-resolution $\delta^{13} \mathrm{C}$ measurements on ancient air extracted from less than $10 \mathrm{~cm}^{3}$ of ice, Tellus, 55B, 138-144, 2003.

Manning, A. C.: Temporal variability of atmospheric oxygen from both continuous measurements and a flask sampling network: Tools for studying the global carbon cycle, $\mathrm{PhD}$ thesis, University of California, San Diego, California, USA, 2001.

Meijer, H. A. J., Neubert, R. E. M., and Visser, G. H.: Cross contamination in dual inlet isotope ratio mass spectrometers, International Journal of Mass Spectrometry, 198, 45-61, 2000.

Pataki, D. E., Bowling, D. R., and Ehleringer, J. R.: Seasonal cycle of carbon dioxide and its isotopic composition in an urban atmosphere: Anthropogenic and biogenic effects, J. Geophys. Res., 108(D23), 4735, doi:10.1029/2003JD003865, 2003.

Schmidt, M., Graul, R., Sartorius, H., and Levin, I.: Carbon dioxide and methane in continental Europe: a climatology, and ${ }^{222}$ Radon-based emission estimates, Tellus, 48B, 457-473, 1996.

Schmidt, M., Glatzel-Mattheier, H., Sartorius, H., Worthy, D. E., and Levin, I.: Western European $\mathrm{N}_{2} \mathrm{O}$ emissions: A top-down approach based on atmospheric observations, J. Geophys. Res., 106, 5507-5516, 2001 
Severinghaus, J. P.: Studies of the terrestrial $\mathrm{O}_{2}$ and carbon cycles in sand dune gases and in Biosphere 2, PhD thesis, Columbia University, New York, USA, 1995.

Severinghaus, J. P., Bender, M. L., Keeling, R. F., and Broecker, W. S.: Fractionation of soil gases by diffusion of water vapor, gravitational settling, and thermal diffusion, Geochim. Cosmochim. Acta, 60, 1005-1018, 1996.

Stephens, B., Bakwin, P., Tans, P., and Teclaw, R.: Measurements of atmospheric $\mathrm{O}_{2}$ variations at the WLEF tall-tower site, in Sixth International Carbon Dioxide Conference, Extended Abstracts, Tohoku Univ., Sendai, Japan, I, 78-80, 2001.

Sturm, P.: Entwicklung eines neuen Einlasssystems für die massenspektrometrische Messung des $\mathrm{O}_{2} / \mathrm{N}_{2}$ Verhältnisses, Master's thesis, Physics Institute, University of Bern, Bern, Switzerland, 2001.

Sturm, P., Leuenberger, M., Sirignano, C., Neubert, R. E. M., Meijer, H. A. J., Langenfelds, R., Brand, W. A., and Tohjima, Y.: Permeation of atmospheric gases through polymer O-rings used in flasks for air sampling, J. Geophys. Res., 109, D04309, doi:10.1029/2003JD004073, 2004.
Sturm, P., Leuenberger, M., Moncrieff, J., and Ramonet, M.: Atmospheric $\mathrm{O}_{2}, \mathrm{CO}_{2}$ and $\delta^{13} \mathrm{C}$ measurements from aircraft sampling over Griffin Forest, Perthshire, UK, Rapid Commun. Mass Spectrom., 19, 2399-2406, doi:10.1002/rcm.2071, 2005a.

Sturm, P., Leuenberger, M., and Schmidt, M.: Atmospheric $\mathrm{O}_{2}$, $\mathrm{CO}_{2}$ and $\delta^{13} \mathrm{C}$ observations from the remote sites Jungfraujoch, Switzerland, and Puy de Dôme, France, Geophys. Res. Lett., 32, L17811, DOI:10.1029/2005GL023304, 2005 b.

Wilkening, M. H. and Clements, W. E.: Radon 222 From the Ocean Surface, J. Geophys. Res., 80, 3828-3830, 1975.

World Meteorological Organisation: $1^{\text {st }}$ International Expert Meeting on Sources and Measurements of Natural Radionuclides Applied to Climate and Air Quality Studies, Gif sur Yvette, France, 3-5 June 2003, Tech. Rep. 155, World Meteorol. Organ. Global Atmos. Watch, Geneva, Switzerland, (2004). 